\title{
SURVIVAL OF BURIED Sclerotinia sclerotiorum SCLEROTIA IN UNDISTURBED SOIL
}

\author{
Ćosić, J. ${ }^{1 *}$, Jurković, D. ${ }^{1}$, Vrandečić, K. ${ }^{1}$, Kaučić, D. ${ }^{2}$ \\ ${ }^{1}$ Faculty of Agriculture in Osijek, Kralja Petra Svačića 1d, 31000 Osijek, Croatia, \\ ${ }^{2}$ State Department of Meteorology, Grič 3, 31000 Osijek, Croatia
}

Received: May 22, 2012

Accepted: June 10, 2012

\section{SUMMARY}

\begin{abstract}
Sclerotia of S. sclerotiorum are surviving structures and the most important source of inoculum in sunflower fields. There are few studies about sclerotia survival in uncultivated soil and in accordance to that our objective was to establish the effect of burial depth on sclerotia longevity and the ability of carpogenic germination. In the trial (2009-2011) sclerotia were buried at the depth of 5,10 and $30 \mathrm{~cm}$ and recovered every year in June. In laboratory sclerotia survival and carpogenic germination were examined. Our results showed that a large percentage of sclerotia survive at least three years under suitable conditions of temperature and moisture. In the case of continuous flooding (2011) sclerotia placed shallow in the soil $(5 \mathrm{~cm})$ were completely destroyed. Achieved results suggest that in undesturbed soil sclerotia placed deeper in the soil $(10$ and $30 \mathrm{~cm})$ stay alive longer than those in upper soil $(5 \mathrm{~cm})$. Regardless of the burial depth sclerotia were able to produce apothecia under laboratory conditions. Resident saprofitic soil fungi (Aspergillus sp., Fusarium sp., Mucor sp. and mycoparasitic Conyothirium sp.) have been isolated equally from alive and deceyed sclerotia, but still less from the viable one.
\end{abstract}

Key words: S. sclerotiorum sclerotia, longevity of sclerotia, carpogenic germination, undisturbing soil

\section{INTRODUCTION}

Sclerotinia sclerotiorum is a cosmopolitan non-specific pathogen on more than 400 plant species, both cultivated and wild (Boland and Hall, 1994; Jurković and Culak, 1997; Vrandečić et al., 2003). In Croatia S. sclerotiorum is one of the main destructive pathogens on sunflower and causes at least three disease types: basal stem rot, rot of upper stem part and head rot. The first two diseases are usually known as white stem rot. All types of diseases have strong impact on yield quantity and quality during cool and wet seasons.

* Corresponding author: Phone ++385 31554 931, Fax ++385 31554 853;

e-mail: jasenka.cosic@pfos.hr 
The major source of inoculum are sclerotia, structures which can remain viable about 4-5 years in soil (Adams and Ayers, 1979) or even longer (Harvey et al., 1995). Sclerotia are deposited on soil surface, below soil level or deeper in soil. But little is known about vertical distribution of sclerotia in soil.

Depending on sclerotia depth, cultural practices, environmental conditions and soil micopopulation sclerotia longevity is different (Adams, 1975; Kurle et al., 2001; Mueller et al., 2002; Duncan et al., 2006). However, results are often very confusing. Merriman et al. (1979) found that percentage of survived sclerotia and apothecia production from bean and lettuce depend on the location and depth of sclerotia burial. Deep plowing decreased density of sclerotia in soil, apothecial formation and sclerotia infection (Mueller et al., 2002). Contrary, Kurle et al. (2001) reported that plowing is not effective in soybean stem rot caused by S. sclerotiorum. Uncultivated soils have higher microbial activity therefore sclerotial degradation should be higher (Workneh and Young, 2000). In unadequate environmental conditions sclerotial survival and germination are diminished. Moore (1949) investigated three flooded soil types and determined that sclerotia were completely destroyed within 24-45 days.

In extensive literature there are few studies about sclerotia survival in undisturbed soil. Since weed and volunteer plants are the hosts for S. sclerotiorum (Jurković and Culek, 1977; Vrandečić et al., 2003) and grow continuously on uncultivated areas this research can be helpful in better understanding of the necessity of their control.

In accordance to that our objective was to study effect of burial depth in undisturbed soil on sclerotia longevity and ability of carpogenic germination.

\section{MATERIAL AND METHODS}

Sclerotia of S. sclerotiorum originating from sunflower plants were collected in summer 2008 (August) and devided into 12 samples, each containing $30 \mathrm{~g}$ of sclerotia of different size as it was found in the field. All samples were place in plastic net-bags, mixed with choped soil and buried for a longer period of time in uncultivated soil at the depth of 5, 10 and $30 \mathrm{~cm}$. The trial started in 2008 and was perfomed during three years.

The first group of samples were dug up after 10 months (June 2009), the second group after 22 months (June 2010) and the third group of samples after 34 months (June 2011). Recovering of sclerotia samples was in June since weather conditions (temperature and precipitation) in June and at the begining of July support sunflower infection.

In the laboratory sclerotia were washed under tap-water $(2 \mathrm{~h})$, surface sterilised (97\% ethil alcohol for 2 min.), rinsed twice in distilled water and air-dried. In Petri dishes $(\varnothing 90 \mathrm{~mm}) 4 \times 10$ sclerotia from each depth were set up on threefold filter paper saturated with distilled water and kept on laboratory desk at $22 \pm 1^{\circ} \mathrm{C}$ upon 
naturally light/dark regime. In every Petri dish there were 5 small $(3-4 \mathrm{~mm})$ and 5 larger $(\geq 4 \mathrm{~mm}$ ) sclerotia. Filter paper moisture was maintained daily with distilled water.

Inspections under stereo microscope (Olimpus SZX9) were done every three days during 27 days.

\section{RESULTS AND DISCUSSION}

Summarized results are presented in Table 1.

Regardless of their size and burial depth the highest percentage (99.2) of all sclerotia survived 10 month burial. Only one larger sclerotia ( $\geq 4 \mathrm{~mm}$ ) buried at the depth of $5 \mathrm{~cm}$ was missing.

Table 1: Effect of burial depth on longevity and carpogenic germination of S. sclerotiorum sclerotia

\begin{tabular}{|c|c|c|c|c|c|c|}
\hline \multirow{2}{*}{ Year } & \multirow{2}{*}{ Depth $(\mathrm{cm})$} & \multirow{2}{*}{$\begin{array}{l}\text { Recovered } \\
\text { sclerotia* }\end{array}$} & \multirow{2}{*}{$\begin{array}{l}\text { Missing } \\
\text { sclerotia }\end{array}$} & \multicolumn{2}{|c|}{ \% sclerotia with stipes** } & \multirow{2}{*}{$\begin{array}{c}\% \text { sclerotia with } \\
\text { apothecia** }\end{array}$} \\
\hline & & & & $3^{\text {rd }}$ day & $27^{\text {th }}$ day & \\
\hline & 5 & 39 & 1 & 25.6 & 51.2 & 2.6 \\
\hline \multirow[t]{3}{*}{2009} & 10 & 40 & 0 & 25.0 & 52.5 & 12.5 \\
\hline & 30 & 40 & 0 & 62.5 & 97.5 & 10.0 \\
\hline & 5 & 36 & 4 & 2.8 & 50.0 & 47.2 \\
\hline \multirow[t]{3}{*}{2010} & 10 & 36 & 4 & 8.3 & 58.3 & 55.5 \\
\hline & 30 & 38 & 2 & 10.5 & 92.1 & 76.3 \\
\hline & 5 & 0 & 0 & 0 & 0 & 0. \\
\hline \multirow[t]{2}{*}{2011} & 10 & 6 & 36 & 83.3 & 100.0 & 16.7 \\
\hline & 30 & 14 & 26 & 42.8 & 71.4 & 21.4 \\
\hline
\end{tabular}

* recovered sclerotia is the number of total (40) sclerotia per depth taken into lab examination

** sclerotia with stipes and sclerotia with apothecia are given as the percentage of number of recovery sclerotia

First stripes, as a wart or very short thread about 1-2 mm long, could be seen under stereo microscope on the $3^{\text {rd }}$ day. This was accepted as a sign of sclerotia survival. Percentage of alive sclerotia continued to increase over the time and on the $27^{\text {th }}$ day ranged from $51.2(5 \mathrm{~cm})$ to $97.5(30 \mathrm{~cm})$. Stripes became longer and reached up to $10 \mathrm{~mm}$. Larger sclerotia produced many stripes, on average 15 per sclerotia, small ones produced fewer stripes (1-3 on average). Despite numerous stripes apothecia with asci and ascospores were infrequent.

Results achieved in 2010 (22 months burial) showed little difference in total percentage of alive sclerotia. It varied from $50.0 \%, 58.3 \%$ to $90.0 \%$ for burial depth of 5,10 and $30 \mathrm{~cm}$, respectively. Appearance of stripes establishesd on the $3^{\text {rd }}$ day was a bit lower in comparison to the previous year. However, till the end of trial the average number of developed stripes was not significantly decreased. Large number of apothecia with developed asci arised, contrary to 2009 results. 
During the next year (June 2010-June 2011) without exception sclerotia buried at $5 \mathrm{~cm}$ were missing and the percentage of sclerotia buried at 10 and $30 \mathrm{~cm}$ significantly decreased. Percentage of recovered sclerotia was only $6(10 \mathrm{~cm})$ and $14(30$ $\mathrm{cm}$ ) and most of them were parasites. According to the data obtained by Moore (1949) sclerotia will be completely decayed after 24-45 days in flooded soil at temperature $22-24^{\circ} \mathrm{C}$. In our case it occured that soil was flooded continually for one month as a consequence of extreme precipitation in May (162 mm) and June (273 $\mathrm{mm}) 2010$ and average soil temperature at $5 \mathrm{~cm}$ was $19.2^{\circ} \mathrm{C}$ in May and $25.4^{\circ} \mathrm{C}$ in June.

Our study showed the development of stripes in a short time. The very first sign of stripe occurring was visible on the $3^{\text {rd }}$ day and their growth was completed in 10 to12 days when they measured $10 \mathrm{~mm}$.

We can not explain why apothecia were rare in 2009 and abundant in 2010. Low preconditioning temperature and continuously high moisture are crucial for carpogenic germination (Huang and Kozub, 1991; Dillard et al., 1995; Harvey et al., 2005; Wu and Subbarao, 2008; Mila and Yang, 2008, Venette, www.ndsu.nodak.edu/ plantpath/sclero.) but since we did not have any preconditioning treatment this could be the reason. In addition, we suppose, burial duration, together with other factors, can effect carpogenic germination (Sun and Yang, 2000; Kurle et al., 2001; Duncan et al., 2005).

In our trial over $50 \%$ of sclerotia buried at $10 \mathrm{~cm}$ and over $90 \%$ buried at $30 \mathrm{~cm}$ remained alive during 22 months and can produce apothecia. On the other hand, Kurle et al. (2001) reported that sclerotia viability decreases in deeper soil under chisel plow and no-tillage cultivation system and sclerotia will carpogenically germinate within upper $5 \mathrm{~cm}$ of soil.

Saprofitic fungi, mostly from genera Aspergillus, Fusarium and Mucor have been found equally on the remaining and destroyed sclerotia. In 2011 Coniothyrium spp., an important mycoparasite of sclerotia of S. sclerotiorum, S. minor, S. trifoliorum, Botrytis cinerea and B. fabae (Cook and Baker, 1983) was isolated especially from destroyed sclerotia. However, sclerotia degradation in deeper soil (10 and $30 \mathrm{~cm}$ ) due to resident soil microogranisms was lower in comparison to sclerotia at $5 \mathrm{~cm}$. Our findings are in agreement with statement by Cook et al. (1975) but not with report by Workneh and Young (2000).

This study confirms the effect of temperature, moisture and also burial depth on longevity of S. sclerotiorum sclerotia. If the environmental conditions are favourable sclerotia will undoubtely survive during almost three years even they are deposited deep in the soil. At the same time achieved results indicate that sclerotia deeper in undisturbed soil ( 10 and $30 \mathrm{~cm}$ ) stay alive for a longer period of time than those at lower depth $(5 \mathrm{~cm})$. It might be connected with weak activity of resident microorganisms in deeper layer of undisturbed soil. Sclerotia which survived under laboratory conditions are also convenient for carpogenic germination. 


\section{REFERENCES}

Adams, P.B. and Ayers, W.A., 1979. Ecology of Sclerotinia species. Phytopathology 69: 896-899.

Boland, G.J. and Hall, R., 1994. Index of plant hosts of Sclerotinia sclerotiorum. Can. J. Plant Pathol. 16: 93-108.

Cook, G.E., Steadman, J.R. and Boosalis, M.G., 1975. Survival of Wetzelinia sclerotiorum and initial infection of dry edible beans in western Nebraska. Phytopathology 65: 250-255.

Cook, R.J. and Baker, K.F., 1983. The Nature and Practice of Biological control of Plant Pathogens. APS St. Paul Minn, pp. 330-332.

Dillard, H.R., Ludwig, J.W. and Hunter, J.E., 1995. Conditioning sclerotia of Sclerotinia sclerotiorum for carpogenic germination. Plant Disease 79: 41 1-415.

Duncan, R.W., Dilantha Fernando, W.G. and Rashid, K.Y., 2006. Time and burial depth influencing the viability and bacterial colonization of sclerotia of Sclerotinia sclerotiorum. Soil Biology \& Biochemistry 38(2): 275-284.

Harvey, I.C., Foley, L.M. and Saville, D.J., 1994. Survival and germination of shallow-buried sclerotia of Sclerotinia sclerotiorum in pasture in Canterbury. New Zeland Journal of Agricultural Research 38: 279-284.

Huang, H.C. and Konzub, G.C., 1991. Temperature requirements for carpogenic germination of sclerotia of Sclerotinia sclerotiorum isolates of different geographic origin. Bot. Bull. Acad. Sin. 32: 279-286.

Jurković, D. and Culek, M., 1997. Abutilon theophrasti Medic.- a new hosts for Sclerotinia sclerotiorum (Lib.) de Bary in Croatia. Acta Phytopathologica et Entomologica Hungarica 32: 307-312.

Kurle, J.E., Grau, C.R., Oplinger, E.S. and Mengistu, A., 2001. Tillage, crop sequence, and cultivar effects of sclerotinia stem rot incidence and yield in soybean. Agronomy Journal 93: 973-982.

Merriman, P.R., Pywell, M., Harrison, G. and Nancarrow, J., 1979. Survival of sclerotia of Sclerotinia sclerotiorum and the effect of cultivation practices on disease. Soil Biology \& Biochemistry 11: 567-570.

Mila, A.L. and Yang, X.B., 2008. Effect of Fluctuating Soil Temperature and Water Potential on Sclerotia Germination and Apothecial Production of Sclerotinia sclerotiorum. Plant Disease 92: 78-82.

Moore, W.D., 1949. Flooding as a means of destroying the sclerotia of Sclerotinia sclerotiorum. Phytopathology 39: 920-927.

Mueller, D.S., Hartman, G.L. and Pedersen, W.L., 2002. Effect of crop rotation and tillage system on sclerotinia stem rot on soybean. Can. J. Plant Pathol. 24: 450-456.

Sun, P. and Yang, X.B., 2000. Light, Temperature, and Moisture Effects on Apothecium Production of Sclerotinia sclerotiorum. Plant Disease 84: 1287-1293.

Vrandečić, K., Ćosić, J., Jurković, D. and Duvnjak, T., 2003. Weeds as inoculum source of Sclerotinia sclerotiorum. Lecture and papers of the $6^{\text {th }}$ Slovenian Conference of Plant Protection, pp. 101-106.

Workneh, F. and Yang, X.B., 2000. Prevalence of sclerotinia stem rot of soybeans in the northcentral United States in relation to tillage. Phytopathology 90: 1375-1382.

Wu, B.M. and Subbarao, K.V., 2008. Effect of Soil Temperature, Moisture, and Burial Depth on Carpogenic Germination of Sclerotinia sclerotiorum and S. minor. Phytopathology 98: 1144-1152. 
